\title{
Sosialisasi Adaptasi Kebiasaan Baru di Masa Pandemi Covid-19 Untuk Ibu-Ibu PKK Kelurahan Gembor, Tangerang
}

\author{
Agus Junaidi', Ahmad Yani², Wahyudin ${ }^{3}$ \\ 1,2,3 Universitas Bina Sarana Informatika \\ J1. Kramat Raya No 98, Senen, Jakarta Pusat, Indonesia \\ e-mail: ${ }^{1}$ agus.asj@bsi.ac.id, ${ }^{2}$ ahmad.amy@bsi.ac.id, ${ }^{3}$ wahyudin.whd@bsi.ac.id,
}

\begin{abstract}
Abstrak
Saat ini pemerintah sedang melaksanakan peraturan pemerintah yang membatasi kegiatan masyarakat selama pandemi virus corona (Corona Virus Deseas). Pelaksanaan perarturan ini tentunya memberikan dampak sosial yang sangat besar bagi kehidupan masyarakat pada umumnya baik secara material maupun immaterial. Pemerintah memberlakukan Pembatasan Sosial Berskala Besar (PSBB) yang mempunyai tujuan agar penularan virus dapat dikendalikan dan dalam jangka panjang dapat dihilangkan sama sekali. PSBB juga membuat masyarakat mengadopsi kebiasaan-kebiasaan baru yang sebelumnya tidak pernah dilakukan, misalnya selalu memakai masker sewaktu keluar dari rumah, rajin mencuci tangan dan lain sebagainya. Hal ini harus diterapkan agar tidak terjadi penularan pada masyarakat. Fakta dilapangan masyarakat mitra dalam kegiatan pengabdian masyarakat masih minim pengetahuan tentang adaptasi kebiasaan baru di masa pandemi Covid-19. Pelaksanaan pengabdian kepada masyarakat ini menggunakan metode deskriptif dan bertujuan memberikan sosialisasi tentang adaptasi kebiasaan baru ditengah pandemi Covid-19 sehingga dapat memberikan informasi yang benar mengenai cara-cara kebiasaan baru yang harus dilakukan dan apa saja yang harus dihindari kepada Ibu-Ibu PKK RW.06 Kel. Gembor, Kecamatan Periuk, Kota Tangerang.
\end{abstract}

Kata Kunci: PSBB; Covid-19; Adaptasi kebiasaan baru

\begin{abstract}
Currently the government is implementing government regulations that limit community activities during the coronavirus pandemic (Corona Virus Deseas). The implementation of this regulation certainly has a huge social impact on people's lives in general both materially and immaterially. The government enforce Large-Scale Social Restrictions (PSBB) that aim to control the transmission of the virus and in the long run can be eliminated altogether. PSBB also makes people adopt new habits that have never been done before, such as always wearing a mask when out of the house, diligently washing their hands and so on. This must be applied so that there is no contagion in the community. The implementation of community service aims to provide socialization about the adaptation of new habits in the midst of the Covid-19 pandemic so as to provide correct information about new ways of habits that must be done and what to avoid to pkk mothers RW.06 Kel. Gembor, Periuk District, Tangerang City.
\end{abstract}

Keywords: PSBB; Covid-19; New Normal 


\section{Pendahuluan}

Dalam masa pandemi saat ini, PSBB menjadi salah satu upaya pemerintah untuk membatasi pergerakan warga agar tidak tertular virus corona. Tetapi dengan terbatasnya pergerakan warga juga menimbulkan dampak yang kurang baik terhadap ekonomi masyarakat. Permasalahan jumlah penghasilan yang makin terbatas juga menjadi masalah tersendiri yang harus dipecahkan oleh para kepala daerah, maupun pejabat pemangku kepentingan. Masih banyak masyarakat yang belum mengetahui bagaimana caranya agar dapat melakukan aktifitas yang terbatas tetapi aman dari penularan virus. Covid-19 (Corona Virus Disease 2019) adalah penyakit yang disebabkan oleh virus severe acute respiratory syndrome coronavirus 2 (SARSCoV-2). Penyakit ini pertama kali menjadi wabah dikota Wuhan, Cina dan selanjutnya menyebar ke seluruh dunia (Astuti et al. 2020). Upaya pemerintah dalam menanggulangi COVID-19 yang dilakukan secara intensif mulai dari awal bulan Maret 2020 telah dapat mengurangi laju penyebaran COVID-19, mengingat adanya kebijakan untuk tatap melakukan aktivitas di rumah mulai dari bekerja, belajar hingga beribadah, sehingga menurunkan angka interaksi sosial yang terjadi di ruang publik dan secara otomatis menurunkan potensi penyebaran COVID19 (Herdiana 2020).

Peraturan pemerintah yang membatasi kegiatan masyarakat selama pandemi virus corona (Corona Virus Deseas) saat ini memberikan dampak sosial yang sangat besar bagi kehidupan masyarakat pada umumnya. Pemerintah memberlakukan Pembatasan Sosial Berskala Besar (PSBB) mempunyai tujuan agar penularan virus dapat dikendalikan dan dalam jangka panjang dapat dihilangkan sama sekali. PSBB juga membuat masyarakat mengadopsi kebiasaankebiasaan baru yang sebelumnya tidak pernah dilakukan, misalnya selalu memakai masker sewaktu keluar dari rumah, rajin mencuci tangan dan lain sebagainya. Hal ini harus diterapkan agar tidak terjadi penularan pada masyarakat. Faktanya masih ada masyarakat masih memerlukan informasi dan edukasi mengenai adaptasi kebiasaan baru di masa pandemi Covid19. Karenanya selaku dosen yang mempunyai kewajiban tridarma perguruan tinggi dalam bidang pengabdian kepada masyarakat untuk memberikan sosialisasi tentang Adaptasi Kebiasaan Baru ditengah pandemi Covid-19 sehingga dapat memberikan informasi yang benar mengenai cara-cara kebiasaan baru yang harus dilakukan dan apa saja yang harus dihindari kepada mitra pengabdian masyarakat dalam hal ini adalah Ibu-Ibu PKK RW.06 Kel. Gembor, Kecamatan Periuk, Kota Tangerang-Banten. Adaptasi Kebiasaan Baru disusun sebagai upaya memulihkan kembali dan mendukung keberlangsungan ekonomi serta aktivitas sektor" yang sempat tersendat oleh penyebaran virus ini, namun dengan cara beriringan dengan upaya pencegahan atau pengendalian penularan virus covid-19 (Br Sembring and Lim 2020). Adaptasi kebiasaan baru juga berhubungan erat dengan pola hidup sehat di masyarakat. Perilaku Hidup Bersih dan Sehat (PHBS) pada dasarnya adalah semua perilaku kesehatan masyarakat yang dilakukan atas kesadaran pribadi. Hal-hal yang diterapkan pada PHBS tergantung dari lingkupnya, misalnya di lingkungan tempat tinggal, sekolah, perkantoran, dan lain-lain (Nurfadillah 2020). Sudah barang tentu dibutuhkan kolaborasi dari semua pihak komponen bangsa (pemerintah, masyarakat) agar apa yang diharapkan semua pihak terwujud yaitu kehidupan yang normal pada semua aspek kehidupan.

\section{Metode}

Metode yang digunakan dalam pengabdian kepada masyarakat ini adalah metode deskriptif dengan langkah sistematis mulai memilih dan merumuskan masalah, menentukan tujuan dari penelitian yang akan dikerjakan, memberikan limitasi dari area atau scope, menentukan 
kerangka konseptual penelitian sampai dengan pembuatan laporan penelitian dengan cara ilmiah. Bentuk kegiatan berupa sosialisasi kepada Ibu-Ibu PKK RW. 06 Kel. Gembor, yang nantinya akan bermanfaat untuk dapat melakukan adaptasi kebiasaan baru dimasa pandemi menggunakan daring (internet) melalui aplikasi zoom meeting. Hal ini dilakukan dengan tujuan untuk mencegah terjadinya penularan virus corona yang disebabkan aktifitas berkumpulnya orangorang dalam jumlah banyak dari berbagai wilayah yang belum diketahui dengan jelas kondisi kesehatannya.

Pengabdian kepada Masyarakat ini dilaksanakan pada Hari Sabtu, Tanggal 26 September 2020 jam 08.00-12.00 WIB melalui Zoom Meeting dengan link https://us02web.zoom.us/j/ 89578186170?pwd=VEhkQng5WWUwVTlzVnNnT1RxMnRxZz09 dan Meeting ID: 895 78186170 dengan Passcode: ubsistmik yang diikuti oleh Ibu-Ibu PKK RW.06 Kelurahan Gembor, Kecamatan Periuk, Kota Tangerang, sebanyak 15 orang.

Secara detail tahapan dalam pelaksanaan pengabdian masyarakat ini, adalah:

1. Analisis kebutuhan

Dilakukan dengan melakukan survey pada analisis kebutuhan Ibu-ibu PKK Kelurahan Gembor, Tangerang mengenai pelaksanaan dan pencegahan covid di lingkungan RW 06.

2. Kajian Pustaka

Tahapan ini dilakukan dengan mencari sumber-sumber referensi yang dibutuhkan untuk kegiatan sosialisasi adaptasi kebiasaan baru untuk masyarakat baik melalui lembaga satgas covid ditingkat keluarahan maupun melalui internet.

3. Persiapan

Tahap persiapan dilakukan dengan membuat slide dan video tutorial untuk adaptasi kebiasaan baru dan mempersiapkan link zoom yang akan digunakan.

4. Sosialisasi

Tahap dimana sosialisasi dilakukan melalui daring dengan aplikasi zoom meeting.

5. Evaluasi

Tahap evaluasi dilakukan dengan memberikan kuesioner melalui link yang dibagikan kepada peserta pengabdian.

\section{Hasil dan Pembahasan}

Perumusan dalam penelitian ini adalah apakah masyarakat mitra pengabdian masyarakat sudah memahami "Adaptasi Kebiasaan Baru di masa pandemi Covid-19?" Dari hasil pengamatan lapangan (observasi) ditemukan fakta bahwa hampir sebagian besar masyarakat mitra pengabdian masyarakat belum mendapatkan informasi dan pemahaman yang baik tetang Adaptasi Kebiasaan Baru di masa Pandemi Covid-19 dan prilaku hidup sehat sebagai bentuk pencegahan perpentiv. Karenanya diperlukan sosialisasi dan edukasi tentang Adaptasi Kebiasaan Baru dan pola hidup sehat kepada masyarakat mitra pengabdian masyarakat.

Menentukan tujuan dari penelitian yang dikerjakan dalam pengabdian masyarakat ini dengan memberikan dan meningkatkan pemahaman, kesadaran kepada masyarakat mitra pengabdian masyakat tentang Adaptasi Kebiasaan Baru dan pola hidup sehat sebagai langkah prepentiv atau pencegahaan penularan virus Covid-19.

Kegiatan penelitian pengabdian masyarakat ini membatasi (limitasi area/scope) hanya kepada masyarakat mitra yaitu Ibu-Ibu PKK RW.06 Kel. Gembor, Kecamatan Periuk, Kota Tangerang- 
Banten. Hal ini dilakukan karena keterbatasan waktu dan sumberdaya yang ada. Kerangka konseptual penelitian derifatif dalam penelitan pengabdian masyarakat ini dengan berupa hipotesis secara implisit yang dapat diverifikasi dengan olahan data kuesioner. Memberikan interpretasi dari hasil analisa data yang diperoleh serta referensi terhadap masalah-masalah yang akan dipecahkan. Mengadakan generalisasi serta dedukasi dari penemuan serta hipotesishipotesis yang dalam hal ini adalah secara imlpisit yang ingin diuji. Setelah itu memberikan rekomnedasi-rekomendasi untuk kebijakan-kebijakan yang dapat ditarik dari penelitian.

Membuat laporan, dalam hal ini pembuatan laporan dilakukan secara ilmiah dan dapat dipertanggungjawabkan secara ilmiah. Hasil yang dicapai dari kegiatan pengabdian masyarakat ini adalah meningkatknya pemahaman dan kesadaran masyarakat terhadap kebiasaan baru (New Normal) selama masa pandemi covid 19, sehingga masyarakat dapat menekan atau memutus mata rantai penyebaran virus covid-19 ini.

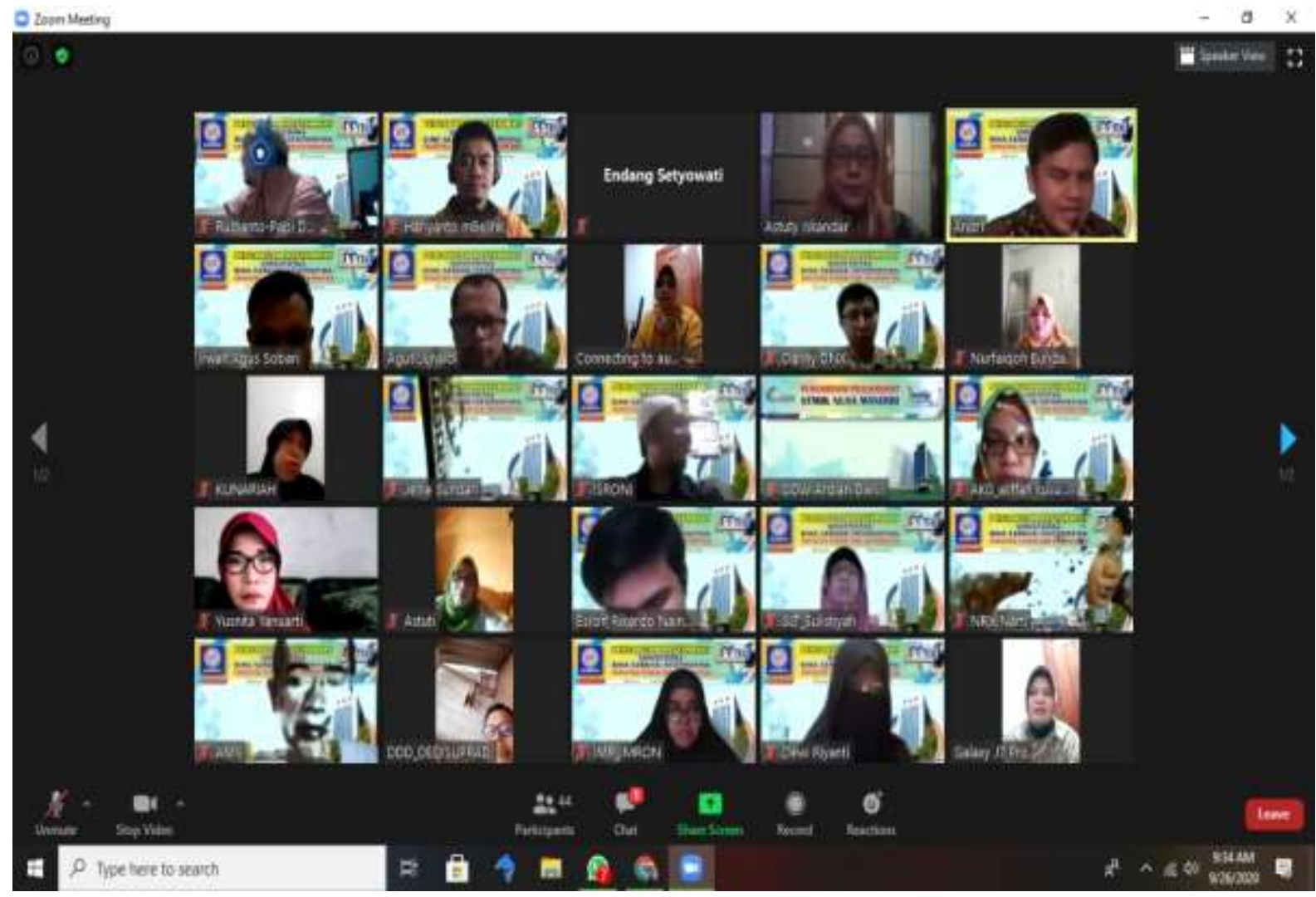

Gambar 1. Peserta Pengabdian Masyarakat PKK RW 06 Kelurahan Gembor

Berdasarkan hasil kuesioner yang telah dibagikan kepada peserta kegiatan pengabdian masyarakat yang dilakukan sebelum dan setelah pelaksanaan, terdapat peningkatan pengetahuan dan pemahaman mitra yang disajikan dalam tabel 1. Hal ini membuktikan bahwa pelaksanaan sosialisasi adaptasi kebiasaan baru dapat memberikan hasil dan manfaat untuk ibuibu PKK RW 06 Keluarahan Gembor, Tangerang. 
Tabel 1. Kualifikasi Pemahaman Mitra

\begin{tabular}{llcc}
\hline No & Parameter & $\begin{array}{c}\text { Nilai Pemahaman } \\
\text { (Sebelum Sosialisasi) }\end{array}$ & $\begin{array}{c}\text { Nilai Pemahaman } \\
\text { (Setelah Sosialisasi) }\end{array}$ \\
\hline 1. & Pandemi Covid-19 & Kurang & Memahami \\
2. & $\begin{array}{l}\text { Adaptasi Kebiasaan Baru } \\
\text { (New Normal) }\end{array}$ & Kurang & Memahami \\
3. & $\begin{array}{l}\text { Prilaku Hidup Sehat } \\
\text { (Preventif) }\end{array}$ & Kurang & Memahami \\
\hline
\end{tabular}

\section{Kesimpulan}

Dengan dilaksanakannya sosialisasi adaptasi kebiasaan baru maka ibu-ibu PKK RW 06 Kelurahan Gembor, Tangerang dapat menerapkan adaptasi kebiasaan baru tersebut dalam segala kegiatan baik diluar maupun didalam rumah. Sosialisasi dan edukasi yang intensif kepada masyarakat tentang bahaya Pandemi Covid-19, adaptasi kebiasaan baru dan prilaku hidup sehat yang diterapkan dapat menahan laju penularan infeksi virus covid-19, sehingga bisa bergerak menuju masa Adaptasi Kebiasaan Baru yang merupakan proses bertahap yang tergantung pada situasi di daerah masing-masing.

\section{Daftar Pustaka}

Astuti, Selvia Febriana et al. 2020. 'Sosialisasi Adaptasi Kebiasaan Baru Di RT 5 / RW 11, Kelurahan Pandemi Covid-19 Counseling About New Normal Adaptation Facing Pandemi Covid-19 At RT 5 / RW 11, Kelurahan Kalisari , Kecamatan Pasar Rebo, Jakarta Timur Kedokteran Universitas Airlangga Em'. 4(2): 448-55.

Br Sembring, Evaliata, and Peter Lim. 2020. 'Edukasi Adaptasi Kebiasaan Baru Di Lingkungan Kampus (Studi Kasus: Motion Graphic Penggunaan Lift)'. Journal Teknik Informatika 3(2): 61-76.

Herdiana, Dian. 2020. 'Penanggulangan COVID-19 Tingkat Lokal Melalui Kebijakan Adaptasi Kebiasaan Baru (AKB) Di Provinsi Jawa Barat'. Journal of Governance Innovation 2(2): 131-56.

KPC-PEN, Satgas Covid-19 -. 2020. 'Ketahui Adapasi Kebiasaan Baru'. Satgas Covid-19. https://covid19.go.id/edukasi/apa-yang-harus-kamu-ketahui-tentang-covid-19/adaptasikebiasaan-baru (January 25, 2021).

Nurfadillah, Rofia Ayu. 2020. 'Perilaku Hidup Bersih Dan Sehat Di Sekolah Pada Masa Adaptasi Kebiasaan Baru (New Normal)'. Jurnal Pengabdian Kesehatan Masyarakat (JPKM) 1(1): 1-6. http://ejurnal.ung.ac.id/index.php/jpkm/index. 